Foss. Rec., 24, 287-294, 2021

https://doi.org/10.5194/fr-24-287-2021

(C) Author(s) 2021. This work is distributed under

the Creative Commons Attribution 4.0 License.

\title{
The southernmost occurrence of Ichthyosaurus from the Sinemurian of Portugal
}

\author{
João Sousa ${ }^{1}$ and Octávio Mateus ${ }^{1,2}$ \\ ${ }^{1}$ GeoBioTec, Faculdade de Ciências e Tecnologia, Universidade Nova de Lisboa, 2829-516 Caparica, Portugal \\ ${ }^{2}$ Museu da Lourinhã, 2530-157, Lourinhã, Portugal
}

Correspondence: João Sousa (pratas.joao@hotmail.com) and Octávio Mateus (omateus@fct.unl.pt)

Received: 23 December 2020 - Revised: 25 July 2021 - Accepted: 5 August 2021 - Published: 9 September 2021

\begin{abstract}
The ichthyosaur fossil record of Portugal is composed of specimens from the localities of São Pedro de Moel, Alhadas, Cadima, Murtede, Casal do Combo, Condeixa, Alvaiázere and Tomar, within the confines of the Lusitanian Basin, ranging in age from the Sinemurian to the Aalenian. We reviewed the historical ichthyosaur finds in Portugal, and in this work we focus on the specimen IST-MDT 85, from the Sinemurian of Praia de Nossa Senhora da Vitória, central west coast of Portugal. The specimen was herein ascribed to Ichthyosaurus cf. communis, based on characters of the humerus in comparison with other specimens. This is the southernmost documented occurrence of Ichthyosaurus, widening the geographical range of the genus.
\end{abstract}

\section{Introduction}

\subsection{Institutional abbreviations}

MG, Museu Geológico de Lisboa, Portugal. IST-MDT, Instituto Superior Técnico de Lisboa, Museu Décio Thadeu, Portugal. NHMUK, Natural History Museum, London.

\subsection{Ichthyosaurus}

Ichthyosaurs are a group of Mesozoic reptiles, who stand out due to their extreme readaptation to a marine environment, being strictly marine organisms, incapable of venturing on land. The genus Ichthyosaurus was restricted to the Late Triassic and Early Jurassic, and geographically is not very widespread, being known mostly from European Early Jurassic formations, although this is considered to be due to lack of proper deposition conditions rather than limitations in species distribution (Sander, 2000). As of the latest research, the genus is comprised of the species I. communis, I. breviceps, I. conybeari, I. anningae, I. larkini, and I. somersetensis (Lomax and Massare, 2017).

\subsection{Ichthyosaurs in Portuguese history}

A majority of the documented ichthyosaur specimens in Portugal (Table 1) were found in Early Jurassic formations during stratigraphy fieldwork performed by the Serviços Geológicos de Portugal. The very first mention of Portuguese ichthyosaurs was made by Paul Choffat, in 1885-1886, mentioning the presence of flattened vertebrae in the Pliensbachian of Pintanheira (Pentelheira), Municipality of Alcobaça. In 1898, Henri Sauvage identified these, alongside a rostrum fragment found in the Aalenian of Alhadas, Municipality of Figueira da Foz, as Ichthyosaurus sp. and compared them to the ichthyosaurs of the English Lias (Sauvage, 1898). Later, Zbyszewski and Moitinho de Almeida (1952) addressed the collections of the Serviços Geológicos de Portugal, reporting maxillary fragments, an anterior right limb, and vertebrae collected by Joaquim Pintassilgo and Ernest Fleury (1878-1958) from the Sinemurian of Praia de Nossa Senhora da Victória, Municipality of Alcobaça, as the species I. intermedius, and maxillary and limb fragments and vertebrae from the Pliensbachian of Pintanheira as Stenopterygius uniter while leaving maxillary fragments from Alhadas (Aalenian) and Murtede (undetermined age - u.a), Municipality of Cantanhede, and vertebrae from Cadima (u.a), Municipality of Cantanhede, and Casal Comba (Casal do Combo), Municipality of Mealhada, as Ichthyosaurus indet. (Zbyszewski and Moitinho de Almeida, 1952). Later, Ferreira (1958) documented a jaw fragment and vertebra from the Pliensbachian of Praia da Nossa Senhora da Victória and vertebrae from the Toarcian of Condeixa, Municipality of 
Condeixa-a-nova, and the Aalenian of Tomar, Municipality of Torres Novas, as $S$. uniter and vertebrae occurrences from the Sinemurian of Praia da Nossa Senhora da Victória, Águas Madeiras (Águas de Madeiros), Municipality of Alcobaça, Casal Comba and the Pliensbachian of Alvaiázere as I. intermedius (Ferreira, 1958). In 2007, Castanhinha and Mateus (2007) reviewed the marine reptiles of Portugal, revising and correcting previous classifications of the documented specimens. This work will focus on IST-MDT 85 , the most complete documented ichthyosaur specimen in the Portuguese fossil record.

\subsection{Geological and geographical context}

All of the ichthyosaur specimens of Portugal were found within the Lusitanian Basin (Fig. 1), its lithostratigraphic units being grouped based on the four rifting episodes that occurred during its evolution (Kullberg et al., 2013). Considering that the Portuguese ichthyosaurs were found in Sinemurian-Aalenian units, this work will address only those which formed during the first two rifting episodes.

The Coimbra Formation, formed in the early Sinemurian during the first rifting episode, $196.5 \mathrm{Ma}$, is a stratigraphic formation of limestones and dolomites (Duarte and Soares, 2002), and in the São Pedro de Moel region, it is particularly well represented, $100 \mathrm{~m}$ thick, with a regional variation between cross-bedded dolomitic limestones and gray marls in the northern Farol area, and gray marly limestones/marls in the southern Água de Madeiros region. Most of these lithostratigraphic units are noted for being rich in fossils of marine species, which, coupled with the carbonate composition of the majority of their sediments, suggests the deposition of these formations occurred in a marine environment, and the observable disappearance of dolomitic facies and increase in fossil presence in the Coimbra Formation suggest a steadily increasing sea level, while the alternating limestone and marl sediments suggest the occurrence of various transgressive cycles, the peaks of which will coincide with the more marly, fossil-rich units (Duarte et al., 2014).

The Quiaios Group, formed in a period from the Pliensbachian to the Aalenian, is comprised of three main formations: Vale das Fontes Formation at the base, with a variable thickness, composed mainly of blackened lumpy marls and marly limestones (Duarte, 2007), the Lemede Formation composed mainly of thick limestones, although there is regional variation (6 $\pm 3 \mathrm{~m}$ in Alvaiázere) (Duarte, 2007) and the S. Gião Formation at the top, composed of limestones and marls, arranged in a laminated cross-bedded pattern, which shows regional variation and is also indicative of tempestiticturbiditic activity (Kullberg et al., 2013).

\section{Methodology}

IST-MDT 85 was determined to require further preparation in the laboratory, leading to the removal of the original plaster support and its substitution with an epoxy layer, as well as removal of sediment with an air scribe, and the cleaning of the specimen with formic acid at $2.5 \%$ and the consequent deacidification process. Once this new preparation was deemed complete, a new description of the specimen was done, and its phylogenetic relations were explored, with IST-MDT 85 being observed, and the phylogenetic characters scored after Moon (2019), with reduced consensus trees being used to improve consensus resolution, and the wildcard taxa originally identified by Moon (2019), Cymbospondylus piscosus, Dearcmhara shawcrossi, Himalayasaurus tibetensis, Isfjordosaurus minor, Maiaspondylus lindoei, Malawania anachronus, Pervushovisaurus bannovkensis, Pervushovisaurus campylodon, Quasianosteosaurus vikinghoegda, Thaisaurus chonglakmanii and Tholodus schmidi being removed prior to the analysis. A 3D model was done with photogrammetry using Agisoft 1.2.0 (see Supplement).

The phylogenetic analysis, by maximum parsimony analysis, was performed using TnT version 1.5 (Goloboff and Catalano, 2016).

The specimen here studied was added to the dataset of Moon (2019). The matrix, comprising 105 terminal taxa coded for 287 characters. Each dataset was analyzed using the new technology search in TNT, including sectorial search, ratchet, drift and tree fusing algorithms, with identical settings as those used by Moon (2019). Then an additional round of tree bisection reconnection using the trees in memory was performed, saving a maximum of 50000 trees per analysis, due to hardware constraints. A pruning consensus algorithm, PCRprun, was then used with the intent of removing problematic taxa from the resulting tree. To optimize analytical time, this search and all the outputs of the analysis of specimen IST-MDT 85 were scripted (see Supplement).

\section{Specimen - systematic paleontology}

Superorder Ichthyopterygia Owen, 1859

Order Ichthyosauria de Blainville, 1835

Family Ichthyosauridae Bonaparte, 1840

Genus Ichthyosaurus König, 1818

Ichthyosaurus cf. communis De la Beche \& Conybeare 1821

\section{Ichthyosaurus cf. communis, IST-MDT 85}

1952, Ichthyosaurus intermedius (cited in Zbyszewski and Moitinho de Almeida, 1952) 
Table 1. Table of the distribution of Portuguese ichthyosaur specimens. MG: Museu Geológico de Lisboa, Portugal; IST-MDT: Instituto Superior Técnico de Lisboa, Museu Décio Thadeu, Portugal.

\begin{tabular}{|c|c|c|c|c|}
\hline Age/stage & Locality & Specimen number & Elements & Referenced by \\
\hline \multirow[t]{3}{*}{ Aalenian } & Alhadas & MG 36 & $\begin{array}{l}\text { Jaw fragments } \\
\text { and teeth }\end{array}$ & Sauvage (1898) \\
\hline & \multirow[t]{2}{*}{ Tomar } & MG 4743 & Dorsal vertebra & \multirow[t]{6}{*}{ Ferreira (1958) } \\
\hline & & MG 4753 & Caudal vertebra & \\
\hline \multirow[t]{2}{*}{ Toarcian } & \multirow[t]{2}{*}{ Condeixa } & MG 25182 & Set of 15 vertebrae & \\
\hline & & MG 25183 & Set of 13 vertebrae & \\
\hline \multirow[t]{5}{*}{ Pliensbachian } & Alvaiázere & MG 25184 & 1 vertebra & \\
\hline & $\begin{array}{l}\text { Praia de Nossa Senhora } \\
\text { da Vitória }\end{array}$ & MG 4749 & $\begin{array}{l}2 \text { maxillary fragments, } \\
\text { with } 46 \text { teeth }\end{array}$ & \\
\hline & \multirow[t]{3}{*}{ Pintanheira } & MG 4751 & Jaw fragments and teeth & \multirow{6}{*}{$\begin{array}{l}\text { Zbyszewski and Moitinho } \\
\text { de Almeida (1952) }\end{array}$} \\
\hline & & MG 4747 & Fin fragments & \\
\hline & & MG 4755 & 38 precaudal vertebra & \\
\hline \multirow[t]{5}{*}{ Sinemurian } & \multirow[t]{3}{*}{$\begin{array}{l}\text { Praia de Nossa Senhora } \\
\text { da Vitória }\end{array}$} & IST-MDT 104 & $\begin{array}{l}\text { Maxillary fragments } \\
\text { with teeth }\end{array}$ & \\
\hline & & IST-MDT 85 & $\begin{array}{l}\text { Anterior right limb, } \\
\text { with articulated radius } \\
\text { and ulna }\end{array}$ & \\
\hline & & IST-MDT 103 & Set of vertebrae & \\
\hline & Águas de Madeiros & MG 4748 & Set of 2 vertebrae & Ferreira (1958) \\
\hline & São Pedro de Moel & MG 4745 & 1 vertebra & Undocumented \\
\hline \multirow{4}{*}{$\begin{array}{l}\text { Uncertain age } \\
\text { (Sinemurian } \\
\text { to Aalenian) }\end{array}$} & Cadima & MG 4752 & Set of articulated vertebrae & \multirow{3}{*}{$\begin{array}{l}\text { Castanhinha and } \\
\text { Mateus (2007) }\end{array}$} \\
\hline & Murtede & MG 35 & $\begin{array}{l}\text { Maxillary fragments } \\
\text { with teeth }\end{array}$ & \\
\hline & Unknown locality & MG 25186 & Rib and vertebrae fragments & \\
\hline & Casal do Combo & MG 4746 & Set of 2 caudal vertebrae & Ferreira (1958) \\
\hline
\end{tabular}

\section{Material}

Forelimbs (IST-MDT 85; Figs. 2 and 3): almost complete left forelimb, in dorsal view, plus disarticulated phalanges from the right limb.

\section{Locality}

Praia de Nossa Senhora da Victória. Cross-referencing the Sinemurian rocks with the original indications by Zbyszewski and Moitinho de Almeida (1952), the probable coordinates are around $39^{\circ} 42^{\prime} 25^{\prime \prime} \mathrm{N}, 9^{\circ} 3^{\prime} 4^{\prime \prime} \mathrm{W}$, in Municipality of Alcobaça, Portugal.

\section{Age and horizon}

In the area, the Sinemurian is observable at Praia de Nossa Senhora da Vitória, in dolomite layers with Unicardium costae (Sharpe) (Zbyszewski and Assunção, 1965), which is the lower section of Coimbra Formation, considered lower Sinemurian (199.3-195.8 Ma).

\subsection{Description}

The more complete left fin is exposed dorsally, with the humerus slightly proximodistally longer than anteroposteriorly wide, and in dorsal view is equally as wide proximally and distally, lacking a differentiated proximal head. The anterior margin is markedly concave, while a proximally reduced anterior flange is present. The dorsal trochanter, a ridge-like structure across the length of the humerus, is observable, 


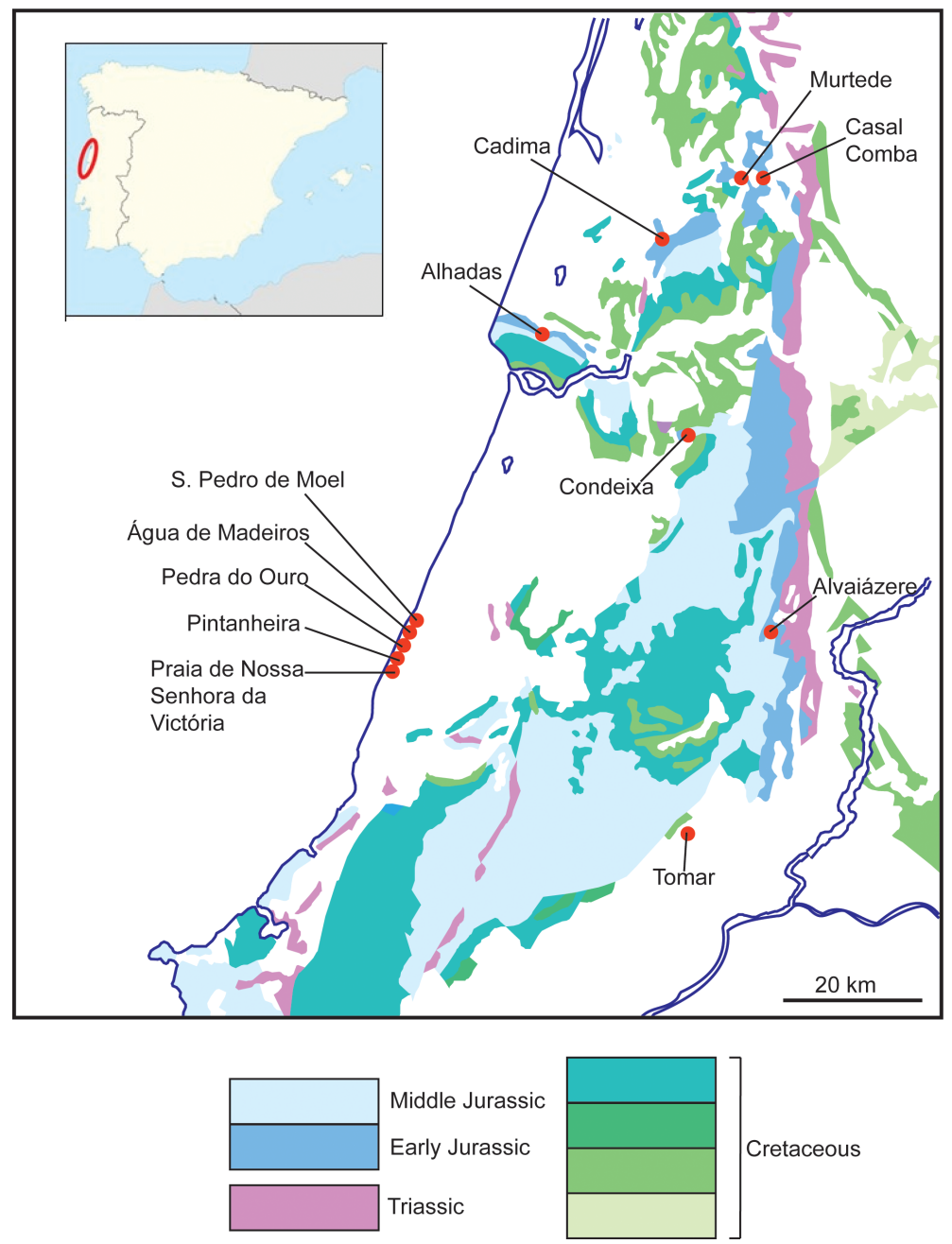

Figure 1. The documented localities where ichthyosaur fossils have been uncovered, within the Lusitanian Basin (locations along the coast are Early Jurassic). Adapted from Blanco (1995).

but a protruding deltopectoral crest and a plate-like dorsal ridge are absent. The distal facets are terminally placed, approximately equal in size, apparently continuous, and the ulnar facet does not deflect posterodistally. The anterodistal extremity shows no tuberosity and no anterior or posteriorly distal facets for the sesamoid. There is no contact between the humerus and the intermedium. The epipodial and metapodial elements are flattened and plate-like, with no notching on the anterior and posterior edges of the fin, and one postaxial accessory digit is observable. The radius and the ulna are equal in size, lacking an interosseous space between them, and the radius is wider than long. The ulna is severely damaged and difficult to discern, but it is apparently equally wide anteriorly and posteriorly, the posterior margin is convex, and as thick as the rest of the ulna. The manual pisiform is absent. The intermedium, damaged like the ulna, is smaller than the ulnare, located between the radius and the ulna, and apparently as wide as it is long, with a pointed proximal shape, an angular distal edge, and two directly supported digits. The ulnare sports one distal facet, supporting a single digit. There are six observable carpals, all of them are of comparable size and a postaxial row of phalanges identified as part of an accessory digit. There are four observable ossified elements in the metacarpal row, and a preaxial accessory digit is absent, with the smaller elements observable on the anterior edge of the fin identified as belonging to the more incomplete right fin, while a postaxial accessory digit is observable. The manual metacarpals ii-iv are polygonal with rounded edges. The 55 observable manual phalanges are tightly packed polygons proximally and growing rounded distally, and a digital bifurcation is observable on the anterior side of the second phalangeal row, apparently stemming from digit iii. 

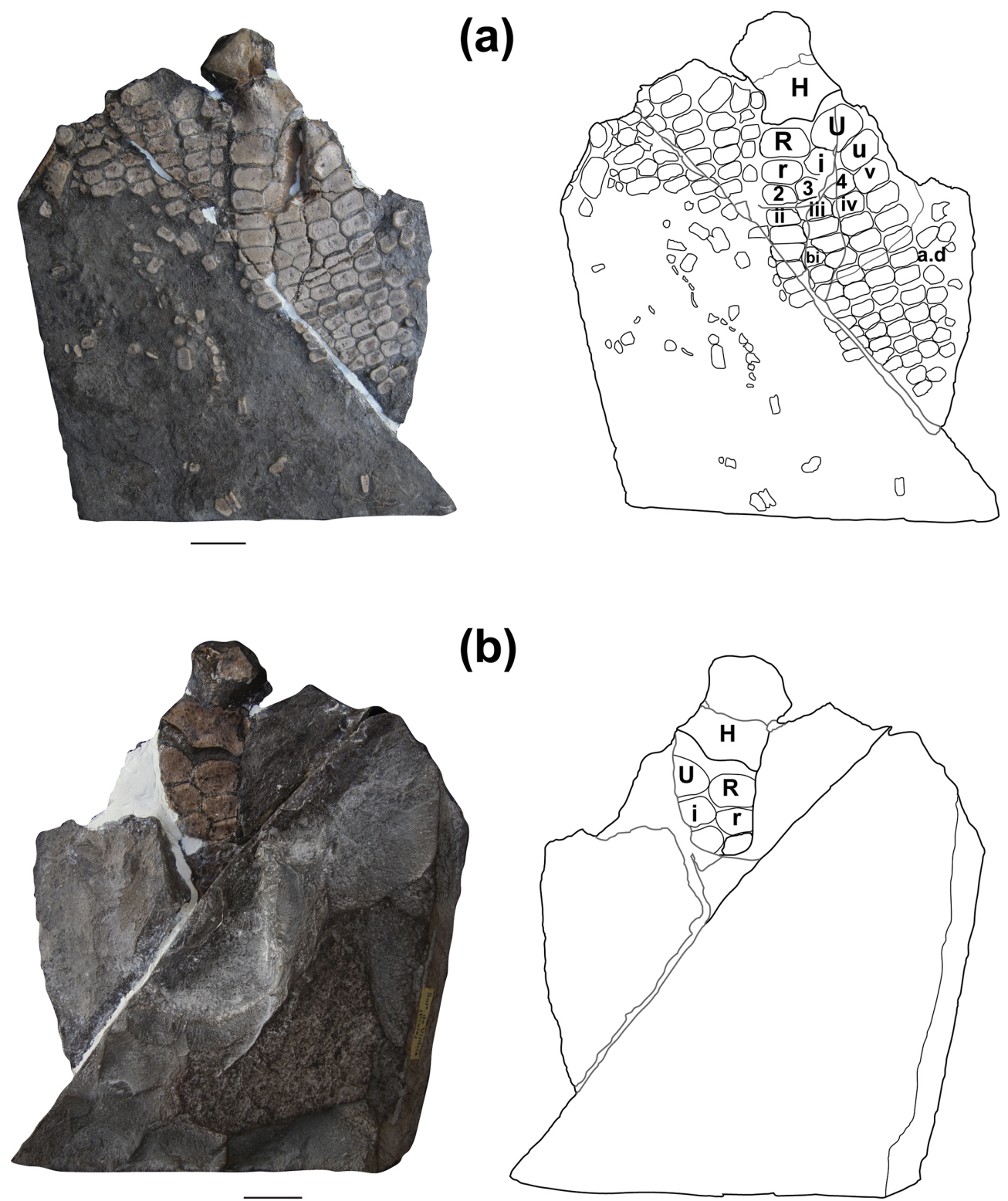

Figure 2. Ichthyosaurus cf. communis (IST-MDT 85), anterior left limb in dorsal (a) and ventral (b) view, from Praia de Nossa Senhora da Victória, São Pedro de Moel. H - humerus; R - radius; U - ulna; r - radial; u - ulnar; i - intermedium; a.d - accessory digit; bi - digital bifurcation; 2-4 - distal carpals; ii-v - metacarpals. Bar marks $2 \mathrm{~cm}$.

\subsection{Phylogenetic analysis results}

Specimen IST-MDT 85 had the following characters scored based on character list by Moon (2019): 198-252: 121 1010?10110 000000101? 2121010001 0101002?1?0 001?1001211. The analysis yielded 50000 MPTs (mostparsimonious trees), each with a length of 1694 steps.

The strict consensus is not well resolved, placing the specimen within the Ichthyosaurus genus (Fig. 4), as determined by the ulnare being larger than the intermedium (Char. 229: $1 \rightarrow 0$ ); the angular distal shape of the intermedium (Char. 233: 1 $\rightarrow$ ); the subequal size of the distal facets of the intermedium (Char. 235: $1 \rightarrow 0$ ); and the four elements on the metacarpal row (Char. 241: $1 \rightarrow 0$ ). Within the genus, the specimen is placed into a polytomy, alongside $I$. communis and I. anningae and a subgroup of $I$. breviceps, I. somersetensis and I. larkini as determined by the humerus being of approximately equal width anteroposteriorly (Char. 206: $0 \rightarrow 1$ ) and the presence of digital bifurcation (Char. 252: $0 \rightarrow 1$ ). 


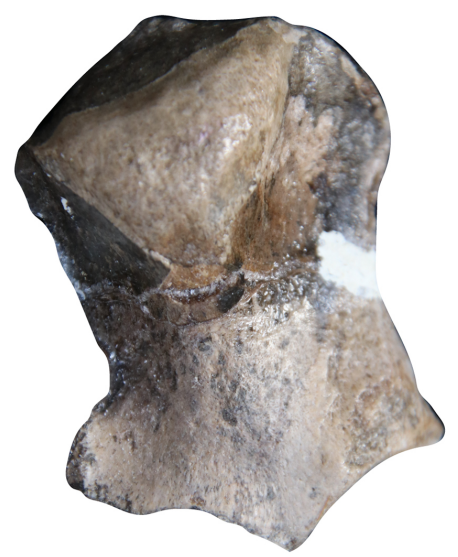

(a)
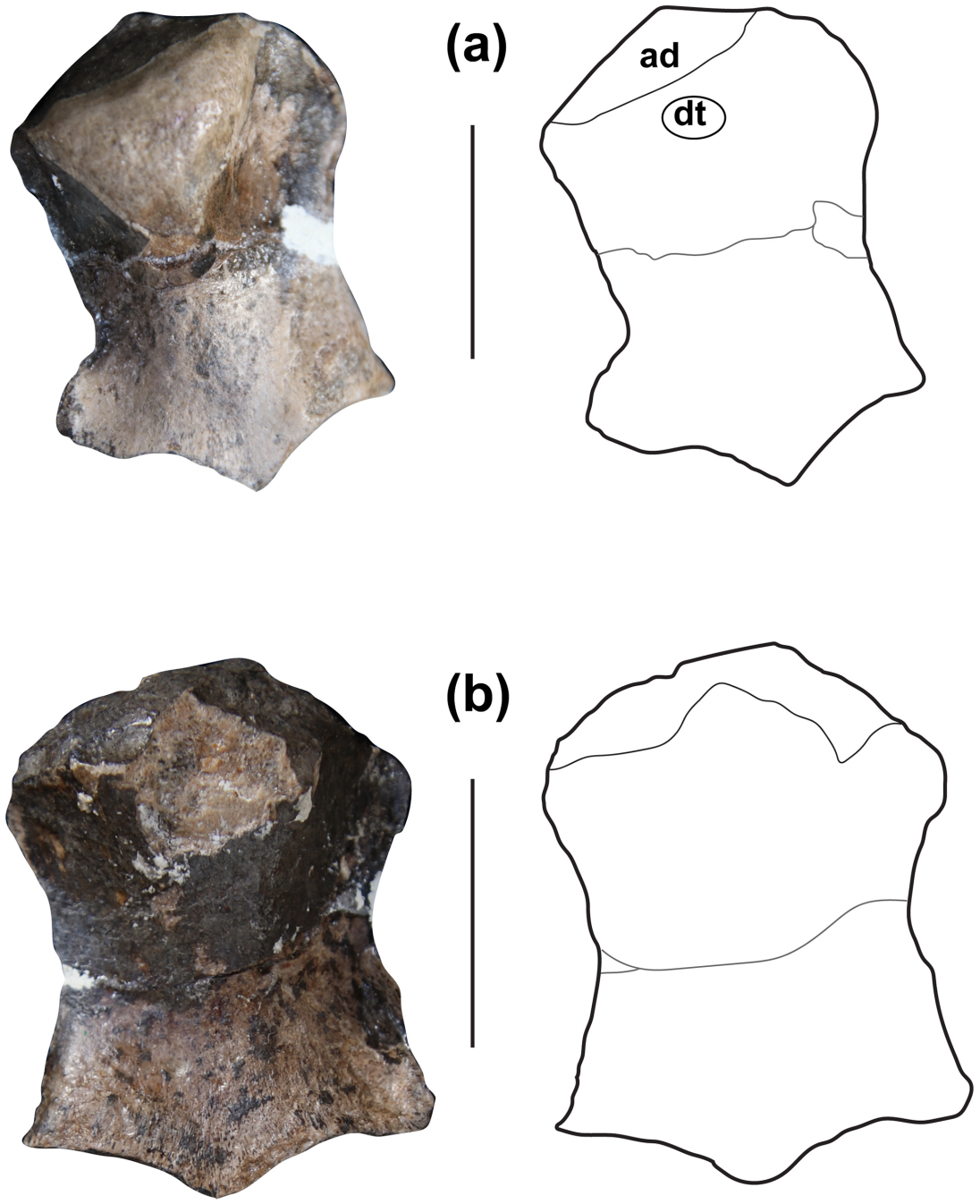

Figure 3. Ichthyosaurus cf. communis (IST-MDT 85), humerus in dorsal (a) and ventral (b) view. from Praia de Nossa Senhora da Victória, São Pedro de Moel. ad - depression in the articular face; $\mathrm{dt}$ - dorsal trochanter. Bar marks $2 \mathrm{~cm}$.

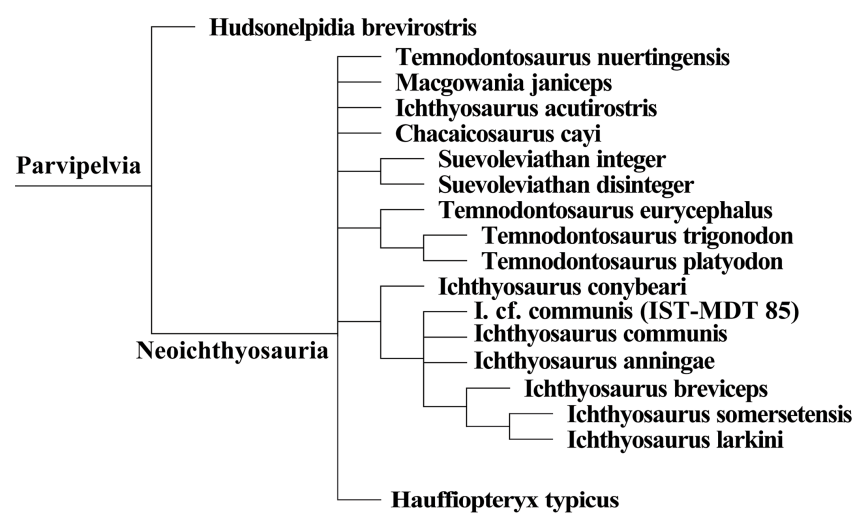

Figure 4. Reduced consensus tree of IST-MDT 85, I. cf. communis, after the matrix by Moon (2019).

\section{Discussion}

IST-MDT 85 was assigned by Zbyszewski and Moitinho de Almeida (1952) to the species I. intermedius, described by Conybeare in 1822, although its holotype location is unknown and what figures of it are available are not considered valid. The species was identified largely through tooth morphology, which nowadays is considered highly variable between individuals and thus not a valid character for species identification, and recent work posits that the species is a synonym to I. communis. Upon observation and comparison with other specimens, it is possible to see that the humerus of IST-MDT 85 shows diagnostic traits of the Ichthyosaurus genus that are observable in I. communis, such as the humerus being longer than wide, the presence of a depression in the articular surface, and the dorsal trochanter being large while extending less than halfway down the shaft (Massare and Lomax, 2018). The phylogenetic analysis further sup- 


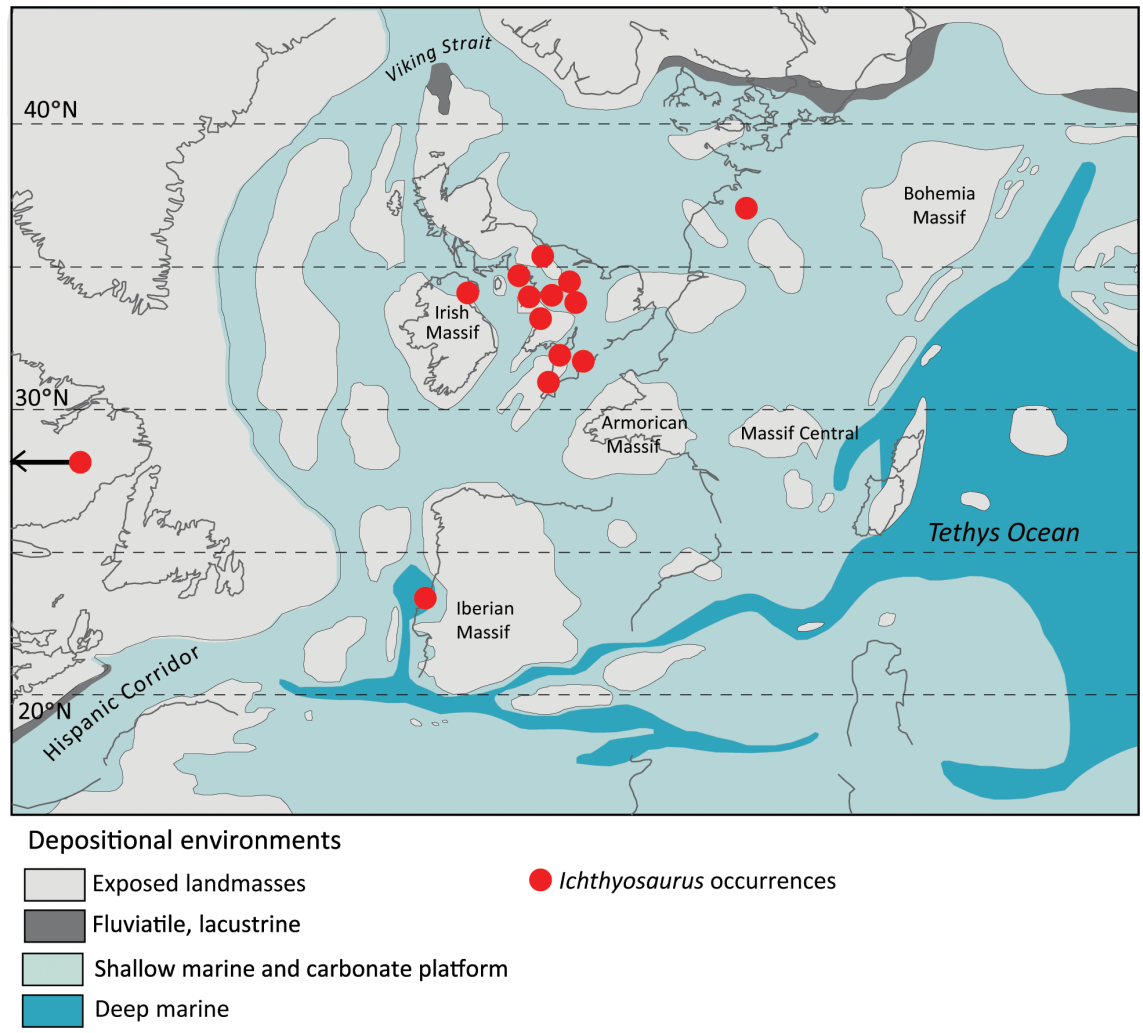

Figure 5. Distribution of Ichthyosaurus sites in the Early Jurassic (the site indicated by arrow is Alberta, Canada), modified from Price et al. (2016).

ports the assignment of the specimen, to the Ichthyosaurus genus, as determined by the absence of notching in anterior elements of the forelimb (Char. 217), and the subequal size of the distal facets of the intermedium (Char. 235), and within this genus placed within a polytomy with $I$. communis and I. anningae, and a subgroup of I. breviceps, I. somersetensis and I. larkini, as determined by the approximately equal anteroposterior width of the humerus (Char. 206), and the presence of manual bifurcation (Char. 252). This last character, observable on the anterior side of the specimen, along with the observable presence of four elements in the distal carpal row, with the distal carpals 3 and 4 being in contact with the intermedium (Motani, 1999), and the humerus being equally as wide proximally and distally while the shaft is lightly constricted (Massare and Lomax, 2018), are identifying elements of Ichthyosaurus, which coupled with the analysis firmly places IST-MDT 85 as part of the genus. While a species identification for the specimen has proven difficult, a comparison to NHMUK PV R1162, the neotype for I. communis (Lomax and Massare, 2017), shows that, while the shaft of the humerus appears to be less constricted in IST-MDT, and identifying a species based on a single, damaged bone is a difficult endeavor, enough similarities are observable to allow us to consider the Portuguese specimen $I$. cf. communis. The Ichthyosaurus genus is very common in
Europe, having occurrences in Belgium (Godefroit, 1996), Northern Ireland, Wales, several localities of England such as Dorset and Somerset (Massare and Lomax, 2018), and one documented occurrence outside of Europe in Alberta, Canada (McGowan, 1978). The I. cf. communis in Portugal is the southernmost occurrence of the genus (Fig. 5).

\section{Conclusion}

In summary, we conclude that IST-MDT 85, the ichthyosaur forelimb from the Sinemurian of Praia de Nossa Senhora da Victória, Municipality of Alcobaça, Portugal, located within the Lusitanian Basin, can be assigned to the Ichthyosaurus genus via phylogenetic analysis, and comparison of traits of the humerus with other specimens further lets us identify it as $I$. cf. communis. This makes IST-MDT 85 the southernmost occurrence of the genus, which expands its geographical range southwards.

Code and data availability. The source code for the matrix, which is based on the matrix by Moon (2019), was obtained from Lloyd (2021, https://graemetlloyd.com). The relevant dataset for the purposes of the article is available in the Supplement. 
Supplement. The supplement related to this article is available online at: https://doi.org/10.5194/fr-24-287-2021-supplement.

Author contributions. This article is a product of JS's master's thesis, of which co-author OM was the advisor. Both authors contributed equally to the research and writing of the article.

Competing interests. The authors declare that they have no conflict of interest.

Disclaimer. Publisher's note: Copernicus Publications remains neutral with regard to jurisdictional claims in published maps and institutional affiliations.

Acknowledgements. We thank Manuel Francisco (Museu Décio Tadeu) as well as Jorge Sequeira and Miguel Ramalho (Museu Geológico de Lisboa) for access to the specimens in their collections, Miguel Moreno Azanza, for assistance in the phylogenetic analysis, Marco Marzola for assistance in developing photogrammetry models of the specimen, and researcher Judith Pardo-Pérez, for revision and comments about the work, and Carla Alexandra Tomás for the preparation assistance.

Review statement. This paper was edited by Torsten Scheyer and reviewed by Judy A. Massare, Benjamin Moon, and Erin Maxwell.

\section{References}

Blanco, L. H.: Mapa Geológico de la Península Ibérica, Baleares y Canarias, Instituto Tecnológico Geominero de España, 1995.

Bonaparte, C. L.: A new systematic arrangement of vertebrated animals, Transactions of the Linnean Society of London, 18, 247304, 1840.

Castanhinha, R. and Mateus, O.: A review on the marine reptiles of Portugal: ichthyosaurs, plesiosaurs and mosasaurs, J. Vertebr. Paleontol., 27, 57A, 2007.

de Blainville, H.: Description de quelques espèces de reptiles de la Californie, précédé de l'analyse d'un système général d'erpétologie et d'amphibiologie, in Nouvelles Annales du Muséum d'Histoire Naturelle, Paris, Vol. 4, 233-296, 1835.

De la Beche, H. T. and Conybeare, W. D.: XXX. - Notice of the discovery of a new Fossil Animal, forming a link between the Ichthyosaurus and Crocodile, together with general remarks on the Osteology of the Ichthyosaurus, Transactions of the Geological Society of London, 1, 559-594, 1821.

Duarte, L. V.: Lithostratigraphy, sequence stratigraphy and depositional setting of the Pliensbachian and Toarcian series in the Lusitanian Basin, Portugal, Ciências da Terra/Earth Sciences Journal, 16, 17-23, 2007.

Duarte, L. V. and Soares, A. F.: Litostratigrafia das séries margocalcárias do Jurássico inferior da Bacia Lusitânica (Portugal), Comun. inst. Geol e Mineiro, 89, 135-154, 2002.
Duarte, L. V., Silva, R. L., Azerêdo, A. C., Paredes, R., and Rita, P.: A Formação de Coimbra na região de S. Pedro de Moel (Oeste de Portugal). Caracterização litológica, definição litostratigráfica e interpretação sequencial, Com. Geol., 101, 421-425, 2014.

Ferreira, O. V.: Novos restos de "Ichthyosauridae" e "Stenopterygidae" encontrados no Lias de Portugal, Comunicações dos Serviços Geológicos de Portugal, 42, 175-181, 1958.

Godefroit, P.: Un crâne d'Ichthyosaurus communis (Reptilia, Ichthyosauria) du Sinémurien supérieur de Lorraine belge, Bulletin de la Société belge de géologie, 104, 77-90, 1996.

Goloboff, P. A. and Catalano, S. A.: TNT version 1.5 , including a full implementation of phylogenetic morphometrics, Cladistics, 32, 221-238, 2016.

König, C. D. E.: Synopsis of the Contents of the British Museum, British Museum (Natural History), London, 1818.

Kullberg, J. C., Rocha R. B., Soares A. F., Rey J., Terrinha P., Azerêdo A. C., Callapez P., Duarte, L.V., Kullberg M. C., Martins L., Miranda J. R., Alves C., Mata J., Madeira J., Mateus O., Moreira M., and Nogueira C. R.: A Bacia Lusitaniana: Estratigrafia, Paleogeografia e Tectónica, edited by: Dias, R., Araújo, A., Terrinha, P., and Kullberg, J. C., Geologia de Portugal no contexto da Ibéria, 2, 195-350, 2013.

Lloyd, G. T.: Contributions, Data, Methods \& Library, available at: https://graemetlloyd.com, last access: 3 September 2021.

Lomax, D. R. and Massare, J. A.: Two new species of Ichthyosaurus from the lowermost Jurassic (Hettangian) of Somerset, England, Pap. Palaeontol., 3, 1-20, 2017.

Massare, J. A. and Lomax, D. R.: A taxonomic reassessment of Ichthyosaurus communis and I. intermedius and a revised diagnosis for the genus, J. Syst. Palaeontol., 16, 263-277, 2018.

McGowan, C.: Further evidence for the wide geographical distribution of ichthyosaur taxa (Reptilia: Ichthyosauria), J. Paleontol., 52, 1155-1162, 1978.

Moon, B. C.: A new phylogeny of ichthyosaurs (Reptilia: Diapsida), J. Syst. Palaeontol., 17, 1-27, 2019.

Motani, R.: On the evolution and homologies of ichthyopterygian forefins, J. Vertebr. Paleontol., 19, 28-41, 1999.

Owen, R.: On the orders of fossil and recent Reptilia and their distribution in time, Report of the British Association for the Advancement of Science, 1859, 153-166, 1859.

Price, G. D., Baker, S. J., VanDeVelde, J., and Clémence, M. E.: High-resolution carbon cycle and seawater temperature evolution during the Early Jurassic (S inemurian-E arly P liensbachian), Geochem. Geophy. Geosy., 17, 3917-3928, 2016.

Sander, P. M.: Ichthyosauria: their diversity, distribution, and phylogeny, Paläontol. Z., 74, 1-35, 2000.

Sauvage, H. E.: Vertébrés fossiles du Portugal: contributions à l'étude des poissons et des reptiles du jurassique et du crétacique, Direction des travaux géologiques du Portugal, Impr. de l'Académie royale des Sciences, Lisbon, 1-68, 1898.

Zbyszewski, G. and Assunção, C. H.: Notícia explicativa da Folha 22-D Marinha Grande, da Carta Geológica de Portugal na escala 1/50.000, Serviços Geológicos de Portugal, Lisboa, 45 pp., 1965.

Zbyszewski, G. and Moitinho de Almeida, F.: Restes d'ichthyosauriens dans de Lias de S. Pedro de Muel, Comunicações dos Serviços Geológicos de Portugal, 33, 5-10, 1952. 